\title{
Using the Delphi method in forecasting tourism activity
}

\author{
Vladimir Modrak ${ }^{1}$, Petre Bosun ${ }^{2}$ \\ ${ }^{1}$ Technical University of Košice, Bayerova 1, 08001, Prešov, Slovakia \\ ${ }^{2}$ University of Timişoara, Vasile Pârvan 2, 300223, Timişoara, Romania \\ E-mail address: bosunpetre@yahoo.com
}

\begin{abstract}
Delphi method is used to obtain usually medium or long-term forecasts, which involves establishing a consensus from a panel of experts asked to make estimates about the evolution of the economical phenomenon. If it cannot be obtain the wished consensus, the opinions having a certain degree of divergence, it aims to reduce as much of this dispersion, without a direct influence on the panel of experts, using a framework in which their expert feedback drive to the conclusion of the study. Of course there are some advantages and disadvantages of this method and these are presented in the article content.
\end{abstract}

Keywords: Delphi method; tourism forecasting; economical aspects; image of a country

\section{INTRODUCTION}

Less used in Romania, Delphi method can be used in tourism to estimate the future trends of the touristic phenomenon on medium and long ranges of time.

The qualitative Delphi technique is a method of collecting the opinions of a group of experts, who remain anonymous through a series of questionnaires and feed-backs in successive stages, expert panel retaining anonymity until the end of the study. The technique follows to achieve a consensus from the experts.

The experts opinions are expressed by writing. After collecting the responses, is made a summary of the opinions, which is distributed to each participant. In this way in every new round, the experts know the others opinions and could change the answers, specifying the argument behind this modification (Borowski, 2013; Traistaru, 2913).

In the recent studies there is no valid study only after obtaining a certain degree of consensus among participants but also after obtaining completely divergent results, which correctly analysed can express the final results with an extreme importance to analysts. 


\section{DELPHI METHOD}

Rowe and Wright (1999) mentioned four defining elements of a Delphi study: the anonymity of the experts, iteration, controlled feedback and statistical aggregation of the results of each iteration.

The difference from Brainstorming method is that the experts do not meet directly. So they will avoid such possible negative influences within the group (dominant experts, fear of the superiors, seizure of discussion from the dinamics and explosives experts, etc.). Usually experts must make a numerical estimate for a given economic variable (Borowski, 2014; Dima, 2013; Vlăduţescu, 2014). The study has a cyclic structure. The questions are about the same in each stage, but before completing the questionnaire, the opinions will be presented to their colleagues (the average apreciation for each question). So the questionnaire may include or exclude certain sections depending on the results of certain stages. The moderator or the leader group process the responses to the questionnaires. It will resume the filling of the questionnaire at least 2 times and it will continue until it can be obtain an consensus and no new ideas will be occuring. The first stage of the questionnaire is sometimes called the definition phase and next stages are phases of convergence.

The expert group size can vary depending on the complexity of the study, being studies involving only four experts, and also studies that included a panel of nearly 100 specialists. Usually, the panel size is about 15 to 20 experts in related areas studied, being very necessary to keep a balance throughout the study. If the number of experts is not very important, balancing the panel is absolutely necessary. When the structure was damaged by the withdrawal of the experts,it is recommended the end of the study.

The answers are quantified based on an defaults scales or simply textually. Despite repeated warnings, if the experts refuse to fill in the questionnaires they will be excluded from the panel of the experts. Often, their participation is encouraged through the granting of financial advantages, but this can sometimes be a bad choice because some experts, to receive their promised rights, automatically participate at study without a purely scientific concern. It is recommended that the chosen experts should be truly interested in the results of the study, their participation in this case being optimal (Dragotă, Dragotă, Ţâţu \& Ţâţu, 2009; Bărbulescu, 2013; Stavre, 2012).

Phased implementation of a Delphi study suppose: the composition of the leadership, setting the problem that will be studied, the choice of the panel of experts, developing questionnaires, the centralization of data and presentation of the expert group, the reiteration and reformulation cycle questionnaires, data of the investigated - analysis, synthesis and interpretation in order to adopt the final results. The periods between two successive questionnaires must be small enough to be able to maintain interest in the subject, but wide enough to give experts time to make a serious analysis and coordination group to allow an analysis and a proper training feedback. A period of 4-6 weeks seems to be sufficient between successive iterations (Smarandache \& Vlăduţescu, 2013; Smarandache \& Vlăduţescu, 2014).

Major discrepancies usually occur in the first stage of completing the questionnaires. In this case, participants are asked to explain with a further argument, their position on the subject. In each round it is recommended the sharing of the information and the reasonings that led to their decision without unveiling their anonymity. The elimination of the divergent opinions without their explanation and analysis, is the safest recipe for failure of a Delphi study, because such people with different opinions, can give up and withdraw, the obtained consent being artificial. 
Of course there are some critics brought to this method. One of them is that it assumes that experts will agree to reconsider their opinions after the feedback. But of course that some members may be inflexible, but the followers of the technique bring the argument that on average, it can reach a certain degree of an consensus, although some experts do not reassess their positions.

Perhaps the strongest charge remains the collapse of the panel of experts, some of them choosing to retire, either because of lack of time or due to loss of their interest for the study in cause. Of course, the followers of the method found a solution by the expert panel sizing with a rate they can accept as acceptable in case of withdrawal from the study of a number of experts.

A third critical factor would be the least resistance, meaning that although opinions seem to converge to an unified direction, in fact, the experts choose to comply with the majority opinion (Vlăduţescu \& Ciupercă, 2013; Avram \& Traistaru, 2014). This may be the result of inadequate consistency of the expert panel. Another difficulty relates to programming the study (clarity of the questionnaires, the establish of the necessary number of experts, choice of the experts, determining optimal response time, etc.). Not eventually it will be considered that the method is quick-and-dirty, too fast (quick) and uncertain (dirty) to be truly useful.

\section{CASE STUDY. PROSPECTS FOR DEVELOPMENT IN KOREA NATIONAL PARKS}

The study was designed to evaluate the future of Korean national parks in protecting the biodiversity and the promoting of tourism.

The research took place in february-march 2001, having in the composition of the panel of experts: specialists in issues of the parks, managers of NGO with activities in environmental issues but also included citizen interested in this problem. It was followed to identify problems that exist for natural parks and how they can be countered.

Each such park is being in a dilemma of preserving the natural qualities on long-term and on the other hand, there is an interest on short-term of the economic benefits of exploitation. The lack of the funds and stuff is one of the major problems for the 20 Korean national parks.

The steering group has set the next steps in managing of this study: (1) identification of the problem, in this case the issues of the parks management in Korea (2) clear and precise preparation of questionnaires, (3) the selection of the panel expert-key (4) fixing at least two iterations, which may possibly be continued until the appearence of a consensus.

The election panel of experts was realised in two stages. Initially, based on the published works, 27 experts were selected from a list of 90 specialists in the field, list recommended by the Korean National Parks Authority (KNPA) and other 9 members selected from the recommendations of the Ministry of Environment and two other NGO. The panel size was set to 36 .

At the first questionnaire, aimed to establish the degree of familiarity of the participants with the subject of study have answered 18 from the 36 panel members, resulting in a Likert scale, an average of 3.94 (5 - meaning the familiar highly, 1 - not at all familiar).

Afterwards, the issues raised by the experts were grouped into three categories: the politics of the park, management of the park, visitor desires. We briefly present some of the most suggestive. 


\begin{tabular}{|l|}
\hline Parks policy issues \\
\hline KNPA and the government generally did not know enough about the \\
issue of the parks; \\
\hline A conflict between preservation and use of the park; \\
\hline Very high percentage of parks is privately owned; \\
\hline Conflicts between local and central administration in the parks; \\
\hline Execution of building temples located within the parks; \\
\hline Lack of an inventory (ecosystem, infrastructure); \\
\hline Increased degradation of parks; \\
\hline The existence of conflicts with temples in parks. \\
\hline \\
\hline Management Issues \\
\hline Low budget and poorly coordinated KNPA; \\
\hline Lack of staff; \\
\hline Lack KNPA experts; \\
\hline There is no conservation standards; \\
\hline Weak management of the ecosystem; \\
\hline Lack of experts in issues of KNPA parks management. \\
\hline \\
\hline Visitor needs issues \\
\hline Lack of education on issues related to ecosystem; \\
\hline Lack of information on parks purposes; \\
\hline Lack of education on environmental issues; \\
\hline Training needs of visitors to not disturb the environment; \\
\hline Poor use of tourist opportunities. \\
\hline
\end{tabular}

In the next steps it was trying to reach a consensus on what is likely to happen, what would be good to happen and the measures to be taken. Finally, the recommendations of the steering group are compared with the evolution of other national parks in Asia, North America and Central America. [Future Of The Korea National Parks: A Preliminary Study of Key Experts Delphi - Byung-Kyu Lee, Wilbur F. LaPage] .

On the subjectivity of the method is perhaps interesting to make a connection between the method name and the oracle from Delphi, whose priestesses murmured whispers in a trance for ordinary people that understood what had to be performed by a prophet interpreter. 
Often the interpretations were the only things that the audience wanted them to hear. This may be a warning of the subiectivism of method (Arhip, 2012; Enachescu, 2013).

\section{CONCLUSION}

With all subjective inconveniences involved in any qualitative techniques, Delphi method certainly is an almost mandatory analysis of initiation on major investment issues and that because it can explain at least the macro framework of the evolution on the interest phenomenon. Even if the results made trough Delphi method may be discussed and interpreted, it is remarkable that this method is usually used when other method of study is no longer applicable. Such results can define the evolution framework of the touristic phenomenon and can impose measures and directions which must to be acted.

\section{References}

[1] G. Rowe, G. Wright, Journal of Forecasting 15 (1999) 353-375.

[2] A. Borowski, International Letters of Social and Humanistic Sciences 11 (2014) 1-168.

[3] B. Ritchie, P. Burns, C. Palmer (Eds.) (2005). Tourism Research Methods. CAB International.

[4] Ştefan Vlăduţescu, European Scientific Journal 9(32) (2013).

[5] I. C. Dima, M. Man (2013). Budgeting and Management Control in Industrial Companies. Saarbrucken: LAP Lambert Academic Publishing.

[6] M. G. Păun, International Letters of Social and Humanistic Sciences 6 (2014) 42-48.

[7] G. Miller, Tourism Management 22 (2001) 351-361.

[8] S. Hillar (2011). Moodle 2.0 Multimedia Cookbook, Packt Publishing.

[9] Alina Țenescu (2009). Comunicare, sens, discurs. Craiova: Editura Universitaria.

[10] G. Kibedi, Revue de Tourism 36 (1981) 3-6.

[11] Ş. Vlăduţescu, E. M. Ciupercă (2013). Next Flood Level of Communication: Social Networks. Aachen: Shaker Verlag.

[12] A. Borowski, International Letters of Social and Humanistic Sciences 3 (2013) 69-74.

[13] M. Siminică, A. Traistaru, International Journal of Education and Research 1(12) 2013.

[14] Lis T., Bajdor P. (2013). Sales Logistics as a Model Used by Companies Fulfilling Individual Customer's Needs. In: Challenges in Contemporary Management. Monograph. Scientific Editors Anna Lemańska-Majdzik, Piotr Tomski, Sekcja Wydaw. WZ PCzęst, Czestochowa.

[15] Ion Stavre (2012). Internet and digital technology - influences on audiovisual communication and on teaching at master's degree level, Valencia, 2012, Published by International Association of Technology, Education and Development - ISBN: 978-84-615-5563-5 
[16] D. Țâţu, R. Bărbulescu, Theoretical and Applied Economics 11(516) (supplement) (vol2)) (2007) 189-192.

[17] Ştefan Vlăduţescu (2013). What Kind of Communication Is Philosophy. Jokull.

[18] Ioan Constantin Dima (2013). Organisational strategies - a systemic approach - on the example of the automotive industry. Saarbrucken: LAP Lambert Academic Publishing.

[19] A. Borowski, International Letters of Social and Humanistic Sciences 4 (2013) 70-74.

[20] Aurelia Traistaru, Elena Antoanela Cotoc (2013). Archiving, Keeping Records and Financial Accounting Documents. International.

[21] I. C. Dima (2013). Industrial Production Management in Flexible Manufacturing Systems. IGI Global USA.

[22] V. A. Enachescu, D. A. Hristache, C. E. Paicu, Review of Applied Socio-Economic Research 4(2) (2012) 93-96.

[23] Aurelia Traistaru (2013). The components of economic record and the research object of Accounting. European.

[24] Ioan Constantin Dima, Ştefan Vlăduţescu (2012). Persuasion elements used in logistical negotiation: Persuasive logistical negotiation. Saarbrucken: LAP Lambert Academic Publishing.

[25] M. G. Mangra, E. A. Cotoc, A. Traistaru, Journal of Studies in Social Sciences 6(1) 2013.

[26] A. Borowski, International Letters of Social and Humanistic Sciences 2 (2014) 110-121.

[27] Dan Ionescu, International Letters of Social and Humanistic Sciences 12 (2014) 57-65.

[28] Marioara Avram, Aurelia Traistaru, International Letters of Social and Humanistic Sciences 13 (2014) 79-88.

[29] F. Smarandache, Ş. Vlăduţescu (2014). Neutrosophic Emergences and Incidences in Communication and Information. Saarbrucken: LAP Lambert Academic Publishing.

[30] Janusz Grabara, Michal Kolcun, Sebastian Kot (2014). The Role of Information Systems in Transport Logistics. International.

[31] Iulian Bitoleanu, International Letters of Social and Humanistic Sciences 9 (2014) 161-121.

[32] I. C. Dima, M. Man, Ş. Vlăduţescu (2012). The Company's Logistic Activity in the Conditions of Current Globalisation. In H. Cuadra-Montiel (Ed.), Globalization, Education and Management Agendas (pp. 263-294). Rijeka: Intech.

[33] F. Smarandache, Ş. Vlăduțescu, (2013). Communication vs. Information, a Neutrosophic Solution. Neutrosophic Sets and Systems.

[34] Vladimir-Aurelian Enachescu, Journal of Community Positive Practices 13(2) (2013).

[35] V. Dragotă, M. Dragotă, L. Obreja, L. Țâţu, A. Ciobanu, A. Racşa (2005). Abordări practice în finanţele firmei. Editura Irecson, Bucureşti.

[36] Byung-Kyu Lee, Wilbur F. LaPage (2003). Future Of The Korea National Parks: A Preliminary Delphi Study Of Key. Experts. 
[37] David R. Austin, Youngkhill Lee, Deborah A. Getz (2008). A Delphi Study of Trends in Special and Inclusive Recreation, Leisure/Loisir. 32: 163-182, 2008 Ontario Research Council on Leisure.

[38] Ştefan Vlăduţescu (2014). Eight computational-communicative operations of building information. Mitteilungen Klosterneuburg.

[39] Răzvan Bărbulescu, Romanian Economic Journal 13(36) (2010).

[40] A. Borowski, International Letters of Social and Humanistic Sciences 6 (2013) 86-90.

[41] Bianca Teodorescu, International Letters of Social and Humanistic Sciences 12 (2014) 73-78.

[42] M. Dragotă, V. Dragotă, L. Ţâţu, D. Ţâţ̧u, Romanian Journal of Economic Forecasting 1 (2009) 76-93.

[43] Ştefan Vlăduțescu (2013). Principle of the Irrepressible Emergence of the Message. Jokull.

[44] O. Arhip (2012). Characteristics of Meta-Referential Discourse. Philologica Jassyensia.

[45] Aurelia Traistaru, Jokull 63(9) 2013 125-135.

[46] Ştefan Vlăduţescu, International Letters of Social and Humanistic Sciences 10(2) (2014) 100-106.

[47] Garrod, B. (2003). Defining marine ecotourism: a Delphi study. Marine Ecotourism: Issues and Experiences, channel view. Publications, Clevedon.

[48] Alexandra Iorgulescu, International Letters of Social and Humanistic Sciences 7 (2014) 14-21.

[49] Jenny Briedenhann, Eugenia Wickens (2000). Combining Qualitative and Quantitative Research Methods. Buckinghamshire Chilterns University College, Wellesbourne Campus, United Kingdom. 